\title{
ANTIBACTERIAL EFFECT OF ORANGE MONASCUS PIGMENT AGAINST STAPHYLOCOCCUS AUREUS
}

\author{
L.H. Feng, Y.Q. LI*, G.J. Sun and X.Z. ZhaO \\ School of Food Science \& Engineering, Qilu University of Technology, Shandong Academy of Sciences, \\ No. 3501 University Road of Changqing District, Jinan, 250353, Shandong Province. China
}

(Received: 9 May 2018; accepted: 4 September 2018)

The objective of this work was to research the antibacterial effects of orange pigment, which was separated from Monascus pigments, against Staphylococcus aureus. The increase of the diameter of inhibition zone treated with orange pigment indicated that orange pigment had remarkable antibacterial activities against $S$. aureus. Orange pigment $\left(10 \mathrm{mg} \mathrm{ml}^{-1}\right)$ had a strong destructive effect on the membrane and structure of $S$. aureus by the analysis of scanning electron microscopy as well as transmission electron microscopy. Sodium dodecyl sulphate-polyacrylamide gel electrophoresis (SDS-PAGE) further demonstrated that the cell membrane was seriously damaged by orange pigment, which resulted in the leakage of protein from S. aureus cells. A significant decrease in the synthesis of DNA was also seen in $S$. aureus cells exposed to $10 \mathrm{mg} \mathrm{ml}^{-1}$ orange pigment. All in all, orange pigment showed excellent antibacterial effects against $S$. aureus.

Keywords: antibacterial effects, orange pigment, S. aureus, cell membrane, DNA synthesis

The microbial contamination problem in food safety is still a fundamental concern of both consumers and the food industry (TANG et al., 2009; Li et al., 2014a). Food preservatives can inhibit the growth of pathogenic and spoilage microorganisms such as $S$. aureus, thereby prolonging shelf life and maintaining freshness of foods (Li et al., 2014a; YANG et al., 2016). Due to the potential toxicity of chemical antimicrobial agents, there is a pressing need to discover natural antimicrobial preservatives (NAVARRo GARCíA et al., 2003; KIM et al., 2010; Li et al., 2014b).

Red yeast rice, as a traditional Chinese food, is the fermented product of rice on which Monascus purpureus has been grown ( $\mathrm{LI}$ et al., 1998; XIE et al., 2012). Monascus purpureus can produce many secondary metabolites, such as pigments, monacolin analogs, $\gamma$-aminobutyric acid (GABA), dimerumic acid, and citrinin (WILD et al., 2002; Su et al., 2005). Monascus purpureus is well known for its ability to produce pigments ranging from bright yellow to deep red. The types of Monascus pigments are yellow pigments, including ankaflavin and monascin; orange pigments, including monascorubrin and rubropunctanin; and red pigments, including monascorubramine and rubropuctamine (WoNG \& KoEHLER, 1981; BLANC et al., 1994). The pigments have been used in food as a natural preservative or to preserve taste and colour in fish and meat (YANG \& MousA, 2012).

The antimicrobial activity of Monascus purpureus was first reported by Wong and BAU (1977). Wild type of Monascus purpureus showed antimicrobial activities against Bacillus, Streptococcus, and Pseudomonas, which are spoilage bacteria in foods (Wong \& BAU, 1977). Two yellow pigments, isolated from Monascus purpureus, had antibacterial activity against

* To whom correspondence should be addressed.
Phone: +86 531 89631195; fax: +86 53189631195 ; e-mails: lyq@qlu.edu.cn; sdililyq@126.com 
Bacillus subtilis (Wong \& Koenler, 1981). The orange pigments had antimicrobial activities against Bacillus subtilis, Escherichia coli, even some filamentous fungi and yeasts (SATO et al., 1997). It had also been reported that Monascus pigments inhibited the growth of Escherichia coli through reducing availability of oxygen in the cells (Kiм et al., 2006b). To the best of our knowledge, little information is available about the antibacterial activities of orange pigment against $S$. aureus, which could produce enterotoxin and be resistant to several antibiotics.

The purpose of this study was to study antibacterial effects of orange pigment against $S$. aureus by detecting inhibition zones and by analysis of morphology, ultrastructure, proteins, and DNA of $S$. aureus cells.

\section{Materials and methods}

\subsection{Preparation of orange pigment solution}

Monascus pigments, purchased from Zhonghui Food Ltd. Co. (Jinan, China), were dissolved in $70 \%$ ethanol to a final concentration of $10 \%(\mathrm{v} / \mathrm{v})$ and extracted at $50{ }^{\circ} \mathrm{C}$ for $2 \mathrm{~h}$. The extracting solution was centrifuged at $4500 \times g$ at $4{ }^{\circ} \mathrm{C}$ for $15 \mathrm{~min}$, then the supernatant was collected in order to extract the orange pigment according to our previously described method (Zнао et al., 2016). Silica gel column chromatography was used to separate orange pigment from the supernatant. The column $(2 \mathrm{~cm} \times 30 \mathrm{~cm})$ was packed with silica gel suspended in $70 \%$ ethanol. Orange pigment was eluted with ethyl acetate. The eluate was concentrated by rotary evaporators (RE-52AA, Yarong Biochemistry Instrument Factory, Shanghai, China) and then freeze-dried (Free Zone 6, Labconco Corporation, Kansas, USA) to get the orange pigment.

\subsection{Bacteria strain and cultivation}

The test strains of S. aureus ATCC 6538 were obtained from the Culture Collection in the Qilu University of Technology (Shandong Academy of Sciences). Freeze-dried bacteria were activated according to the ATCC guidelines. The strain was maintained on the slants of beef extract peptone (BEP) medium $(0.3 \%$ beef extract, $1 \%$ peptone, $0.5 \% \mathrm{NaCl}$, and $2 \%$ agar boiled to dissolve in $100 \mathrm{ml}$ of distilled water) and inoculated into $100 \mathrm{ml}$ of sterile BEP broth. The BEP broth was cultivated with shaking $(130$ r.p.m. $)$ at $37^{\circ} \mathrm{C}$ for $9 \mathrm{~h}$ to yield a final cell concentration of $10^{7}-10^{8} \mathrm{CFU} \mathrm{ml}^{-1}$ used for further study.

\subsection{Measurement of inhibition zone diameters}

Orange pigment was dissolved in sterile distilled water to final concentrations (w/v) of 0.625 , $1.25,2.5,5$, and $10 \mathrm{mg} \mathrm{ml}^{-1}$, respectively. Antibacterial activities of orange pigment against S. aureus were measured by the Oxford cup method (WANG et al., 2009) with some modifications. S. aureus cells (approximately $10^{8} \mathrm{CFU} \mathrm{ml}^{-1}$ ) were harvested and diluted with phosphate buffer solution (PBS, $10 \mathrm{mM}, \mathrm{pH} 7.4$ ) to a final concentration of $10^{5} \mathrm{CFU} \mathrm{ml}^{-1}$. An

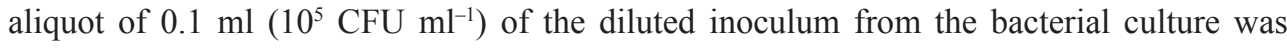
transferred to the surface of BEP medium plates. Each strain was spread evenly onto individual plates through a glass spreader. Sterile Oxford cups $(5 \mathrm{~mm})$ were placed on the surface of plates poured with BEP medium in a regular triangle distribution. Aliquots of $200 \mu \mathrm{l}$ of varying orange pigment concentrations $\left(0.625,1.25,2.5,5.0\right.$, and $\left.10 \mathrm{mg} \mathrm{ml}^{-1}\right)$ were 
transferred into each Oxford cup, respectively, and $200 \mu \mathrm{l}$ of sterile water was added in place of orange pigment as control. These plates were placed in the refrigerator at $4{ }^{\circ} \mathrm{C}$ for $2 \mathrm{~h}$ and incubated at $37^{\circ} \mathrm{C}$ for 2 days. Then the diameters of the transparent inhibition zones were measured.

\subsection{Scanning electron microscopy (SEM) analysis of S. aureus cells}

SEM analysis was performed to observe the morphological changes of $S$. aureus cells (Booyens et al., 2014). Aliquots $(5 \mathrm{ml})$ of the $S$. aureus culture treated with orange pigment at 0 and $10 \mathrm{mg} \mathrm{ml}^{-1}$ were incubated at $37^{\circ} \mathrm{C}$ with gentle agitation for $4 \mathrm{~h}$. After centrifugation at $6000 \times g$ for $15 \mathrm{~min}$, the precipitated S. aureus cells were washed twice in PBS $(10 \mathrm{mM}$, $\mathrm{pH}$ 7.4) and fixed in $2.5 \%$ glutaraldehyde for $12 \mathrm{~h}$. The fixed cells were washed three times with PBS (10 mM, pH 7.4) and dehydrated in alcohol (30, 50,70, 80, 90, and 100\%, one time at $20 \mathrm{~min}$ for each dilution and three times at $30 \mathrm{~min}$ at the last step). The dehydrated cells were dried by $\mathrm{CO}_{2}$ critical point drying, mounted onto SEM specimen stubs and coated with gold, then observed by SEM (S-570, Hitachi, Tokyo, Japan).

\subsection{Transmission electron microscopy (TEM) determination of $\mathrm{S}$. aureus cell ultrastructure}

The cell ultrastructure of $S$. aureus was studied using TEM according to the previously described method (ZHAO et al., 2017). A series of quantity of orange pigment were added to the bacterial suspensions $(5 \mathrm{ml})$ to get final concentrations of 0 to $10 \mathrm{mg} \mathrm{ml}^{-1}$. The bacteria treated with orange pigment were incubated at $37^{\circ} \mathrm{C}$ for $4 \mathrm{~h}$. The treated cells were harvested by centrifugation at $6000 \times g$ for $15 \mathrm{~min}$ and washed twice in PBS $(10 \mathrm{mM}, \mathrm{pH}$ 7.4). Then the cells were fixed with $2.5 \%$ glutaraldehyde at $4{ }^{\circ} \mathrm{C}$ for at least $2 \mathrm{~h}$ and oxidised by adding $200 \mu \mathrm{l}$ of $1 \%$ osmium tetroxide at $4{ }^{\circ} \mathrm{C}$ for $3 \mathrm{~h}$. After oxidation, the cells were dehydrated sequentially using different acetone solutions $(30 \%, 50 \%, 70 \%, 90 \%$, and $100 \%)$. Finally, the dehydrated pellets were transferred into embedding plate, then permeated twice with 1,2-epoxypropane for $10 \mathrm{~min}$ and with epoxy resin (DER: DMAE: ERL: NSA = 1.80: 0.06: 2.00: 5.00) at $4{ }^{\circ} \mathrm{C}$ for $45 \mathrm{~min}$ before drying $\left(70{ }^{\circ} \mathrm{C}, 18 \mathrm{~h}\right)$ to form specimen blocks. TEM (JEOL-JEM-1200 EX, Japan) was used to observe the section of samples.

\subsection{Sodium dodecyl sulphate polyacrylamide gel electrophoresis (SDS-PAGE) of the proteins of $\mathrm{S}$. aureus cells}

SDS-PAGE of the bacterial proteins was carried out after incubation with the antimicrobial agent (SітонY et al., 2012). Aliquots $(2 \mathrm{ml})$ of different concentrations of orange pigment were added to $18 \mathrm{ml}$ bacterial culture solutions (approximately $10^{8} \mathrm{CFU} \mathrm{ml}^{-1}$ ) to final concentrations of 0 to $10 \mathrm{mg} \mathrm{ml}^{-1}$. The bacterial suspensions of the control group were immediately centrifuged at $6000 \times g$ for $15 \mathrm{~min}$. The treated bacterial suspensions were incubated at $37{ }^{\circ} \mathrm{C}$ for $4 \mathrm{~h}$ and then centrifuged at $6000 \times g$ for $15 \mathrm{~min}$. The obtained pellets were washed twice with PBS (10 mM, pH 7.4) and resuspended in $1 \mathrm{ml}$ PBS (10 mM, pH 7.4). Aliquots $(50 \mu \mathrm{l})$ of bacterial suspensions were mixed with $25 \mu \mathrm{l}$ of the sample buffer (pH 6.8; $1 \mathrm{M}$ Tris- $\mathrm{HCl}, 50 \%$ glycerol, $10 \%$ SDS, $10 \% \beta$-mercaptoethanol, and $0.1 \%$ bromophenol blue), heated at $100^{\circ} \mathrm{C}$ for $3 \mathrm{~min}$, cooled to $25^{\circ} \mathrm{C}$, then treated with ultrasonic for $3 \mathrm{~min}$, and loaded onto a $3 \%$ stacking and $12 \%$ resolving gel. The proteins were run at 10 $\mathrm{mA}$ for $30 \mathrm{~min}$ on the stacking gel and at $20 \mathrm{~mA}$ for $2 \mathrm{~h}$ on the resolving gel. The gel was dyed by Coomassie Brilliant Blue R250 and decolorized by decolouring agent. After 4 days, protein bands were visualized on the gels. 


\subsection{DNA assay}

Aliquots $(5 \mathrm{ml})$ of the $S$. aureus culture treated with orange pigment at 0 to $10 \mathrm{mg} \mathrm{ml}^{-1}$ were incubated at $37^{\circ} \mathrm{C}$ with gentle agitation for $4 \mathrm{~h}$, then harvested by centrifugation at $6000 \times \mathrm{g}$ for $15 \mathrm{~min}$ and washed twice in PBS (10 mM, pH 7.4). DNA was extracted with the bacterial DNA extraction kit (Bioteke corporation, Beijing, China). Lastly, samples were applied to a $1.0 \%$ agarose gel electrophoresis and run at $200 \mathrm{~V}$ for $15 \mathrm{~min}$, then observed under UV illumination through gel imaging system.

\subsection{Statistical analysis}

Every experiment was performed in triplicate, and average values with standard errors are reported. SPSS17.0 software was used for all statistical analyses. The data were analyzed by analysis of variance (ANOVA) and Duncan's post-hoc analysis, and regression analysis was used to determine the significant difference at $5 \%$ confidence intervals $(\mathrm{P}<0.05)$.

\section{Results and discussion}

\subsection{Antibacterial activities of orange pigment against $\mathrm{S}$. aureus}

The antibacterial activities of orange pigment against $S$. aureus were evaluated by the diameter of the inhibition zones (Table 1). As observed in Table 1, the diameters of the inhibition zones against $S$. aureus increased from $5.0 \pm 0.3 \mathrm{~mm}$ to $34 \pm 1.3 \mathrm{~mm}$ with increasing concentrations of orange pigment from 0 to $10.0 \mathrm{mg} \mathrm{ml}^{-1}$. These results demonstrated that orange pigment had antibacterial activities against $S$. aureus. Moreover, its antibacterial activities increased with the increase of orange pigment concentration.

Table 1. Inhibition zone diameters of S. aureus treated with varying concentrations of orange pigment

\begin{tabular}{lcccccc}
\hline Treatments & \multicolumn{5}{c}{ Concentrations of orange pigment $\left(\mathrm{mg} \mathrm{m}^{-1}\right)$} \\
\cline { 2 - 7 } & 0 & 0.625 & 1.25 & 2.50 & 5.00 & 10.00 \\
\hline Inhibition zone diameters $(\mathrm{mm})$ & $5.0 \pm 0.3^{\mathrm{a}}$ & $24 \pm 1.8^{\mathrm{a}}$ & $26 \pm 1.5^{\mathrm{a}}$ & $27 \pm 2.0^{\mathrm{a}}$ & $33 \pm 0.9^{\mathrm{b}}$ & $34 \pm 1.3^{\mathrm{b}}$ \\
\hline
\end{tabular}

Different superscript lowercase letters $\left({ }^{\mathrm{a}, \mathrm{b}}\right)$ indicate significant differences at $\mathrm{P}<0.05$.

UnguREANU and Ferdes (2010) reported antibacterial activities of Monascus red rice powder against Bacillus, Pseudomonas, and Streptomyces spp., proposing that the pigments of Monascus purpureus might be a preservative applied in food. A similar report indicated that the Monascus red pigments exhibited high antibacterial activities against S. aureus, Escherichia coli, and Bacillus subtilis by using the minimum inhibitory concentration (КІм et al., 2006a).

\subsection{Effect of orange pigment on the morphological changes of $\mathrm{S}$. aureus cells}

The morphological changes of $S$. aureus cells were evaluated by SEM analysis. Figure 1 displays SEM photomicrographs of S. aureus cells treated with and without orange pigment. As observed in Figure 1A, the untreated S. aureus cells had typical regular and plump 
appearance with uniform size and distribution. However, S. aureus cells treated with orange pigment had irregularly wrinkled outer surface and were not uniform in size and distribution. Furthermore, there were some adhesion and aggregation of damaged cells or cellular debris (Fig. 1B). These changes in the morphology of S. aureus indicated that orange pigment treatment resulted in the destruction of the bacteria.

A

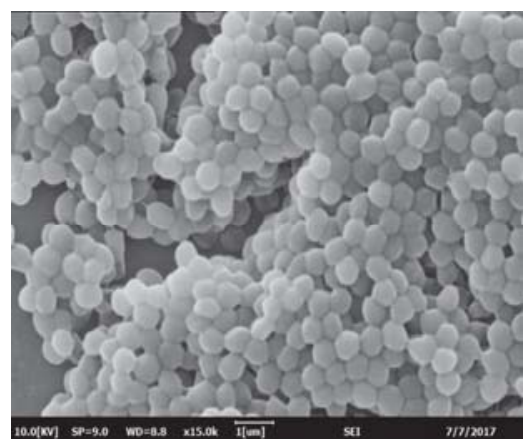

B

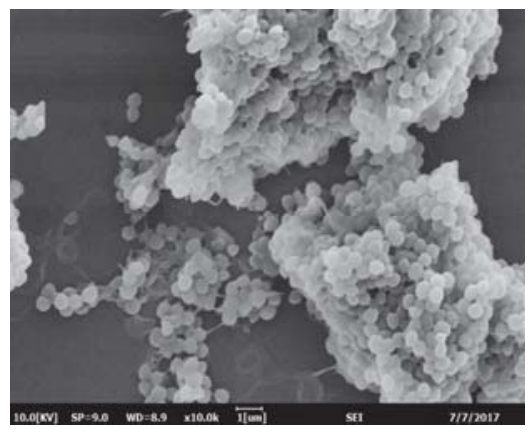

Fig. 1. SEM photomicrographs of S. aureus cells treated with orange pigment. (A) S. aureus treated without orange pigment, (B) S. aureus treated with $10 \mathrm{mg} \mathrm{ml}^{-1}$ orange pigment

Our SEM photomicrographs of $S$. aureus treated with orange pigment were similar to Escherichia coli cells, which had irregular and wrinkled surfaces when treated with orange pigment, compared to regular and smooth surfaces of untreated cells (Zнао et al., 2016). The Escherichia coli cells in the presence of Monascus red pigments were obviously damaged with large pellets and aggregation, just as the $S$. aureus exposed to orange pigment with cellular debris and adhesion (KIM et al., 2006b).

\subsection{Effect of orange pigment on the ultrastructure of $\mathrm{S}$. aureus cells}

TEM was used to observe the ultrastructural changes of the orange pigment treated cells. TEM imaging of the control experiments exhibited intact membrane and uniform morphology (Fig. 2A). Compared with the control, various morphological and intracellular changes of orange pigment-treated cells were seen in the cell membrane and cytoplasm (Fig. 2B). S. aureus cells were irregular and wrinkled, with outflow of some part of cytoplasm from the cells. These phenomena further indicated the damage of orange pigment to the ultrastructure of S. aureus cells. This present study was in agreement with the finding that cells showed a normal rod or spherical shape in the control group, whereas cells had a thin and wrinkled layer of pigment on the cell surface in Monascus red pigment treated S. aureus via TEM observation (Kim et al., 2006b).

\subsection{Effect of orange pigment on the leakage of the bacterial proteins}

SDS-PAGE of the bacterial proteins from the $S$. aureus cells treated with orange pigment is shown in Figure 3. The types and amounts of protein in S. aureus treated with orange pigment were less than the control. There were two bands with molecular weight of approximate 25 $\mathrm{kDa}$ in the control. However, the two bands almost disappeared in the treated samples. The 
reason of the decrease or disappearance in bacterial proteins of the treated samples might be that orange pigment seriously damaged the $S$. aureus, thus resulted in the leakage of protein from the bacterial cells, which was consistent with the result of the ultrastructure of S. aureus cells (Fig. 2).

A

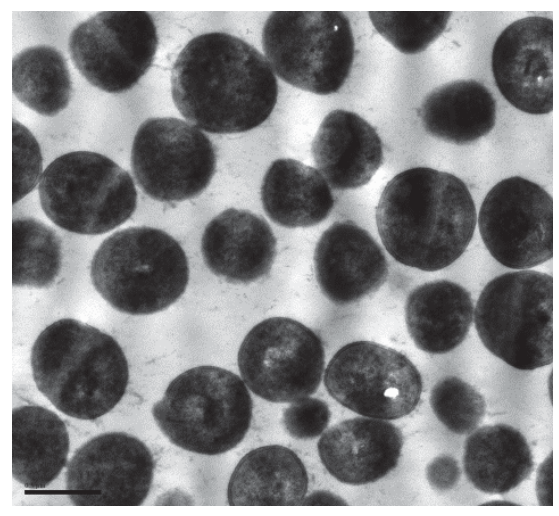

B

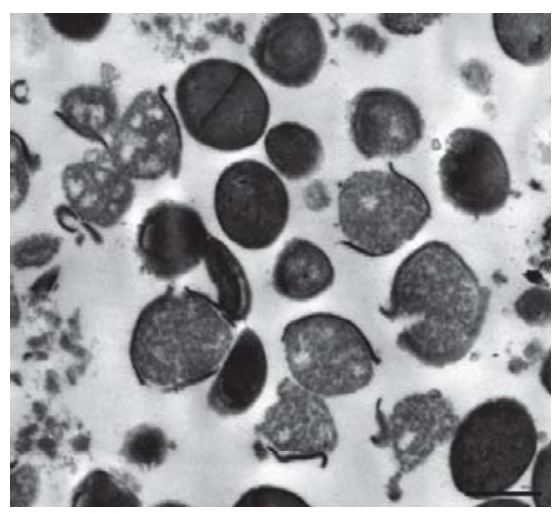

Fig. 2. TEM imaging of S. aureus cells treated with orange pigment. (A) S. aureus treated without orange pigment, (B) $S$. aureus treated with $10 \mathrm{mg} \mathrm{ml}^{-1}$ orange pigment

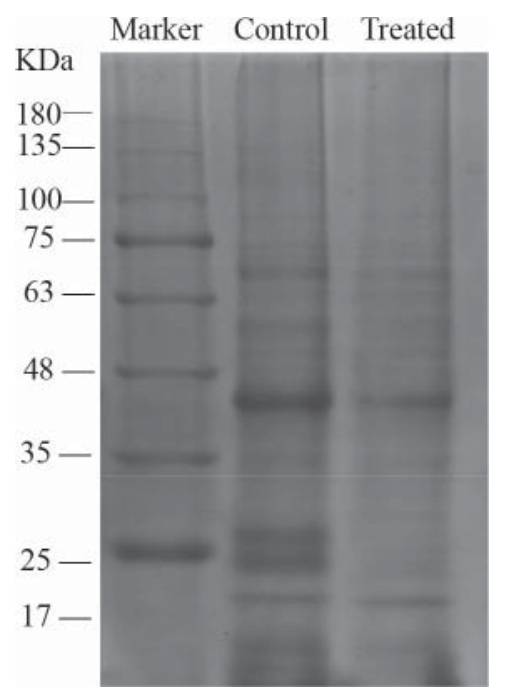

Fig. 3. Effect of orange pigment on proteins of S. aureus cells

CLOETE and co-workers (2009) suggested that anolyte caused bacterial death by complete destruction of or partially degrading proteins. It has also been reported that protein patterns of Listeria monocytogenes and Salmonella enteritidis treated with $100 \mu \mathrm{g} \mathrm{ml}^{-1}$ of glycinin basic subunit showed early the fading of most bacterial protein bands, indicating glycinin basic subunit caused the leakage of the bacterial protein (Sітону et al., 2012). 


\subsection{Effect of orange pigment on the bacterial DNA}

The effect of orange pigment on the bacterial DNA is showed in Figure 4. The amounts of DNA in S. aureus treated with orange pigment were less than that in the control group. The reason of the decrease in bacterial DNA might be that orange pigment could destroy the $S$. aureus cells, further influence its growth and synthesis of DNA. The present result was consistent with the finding of WANG and co-workers (2010), who indicated soybean isoflavone affected nucleic acid synthesis and inhibiting bacterial growth, proved by the agarose gel electrophoresis analysis of DNA.

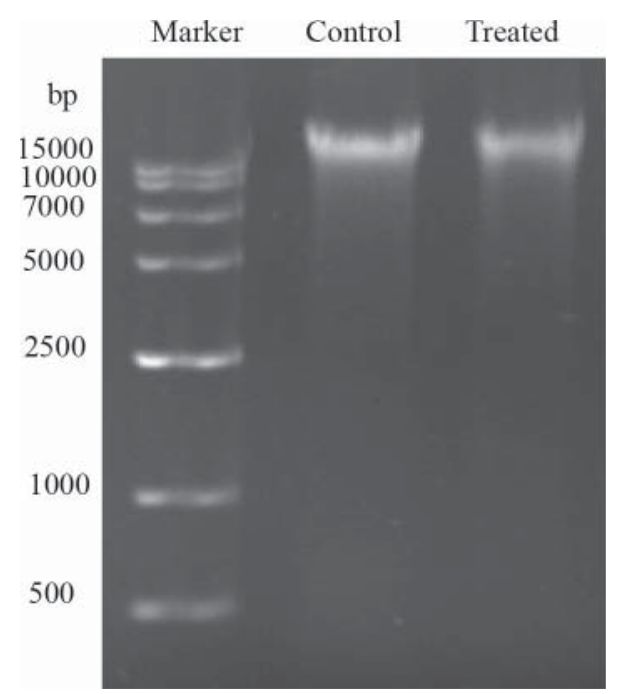

Fig. 4. Effect of orange pigment on DNA of S. aureus cells

\section{Conclusions}

In a word, these results showed that orange pigment exhibited antibacterial effects on $S$. aureus. The antibacterial actions of orange pigment might be that it damaged cell membrane of bacterial cells, and made some cellular components such as proteins and DNA let out, consequently resulting in the death of bacterial cells. Thus orange pigment might be a potential natural food preservative in food industry.

The authors would like to express their gratitude to Major Plan of Studying and Developing (2018YYSP001), Funds of Shandong "Double Tops" Program (SYT2017XTTD04), 2017-year Support Program for Introduction of Urgently-needed talents in Western Economic Upwarping Zone and Poverty-alleviation-exploitation Key Area in Shandong Province, as well as the Program for Science and Technology Innovation Team in Universities of Henan Province (16IRTSTHN007).

\section{References}

Blanc, P.J., Loret, M.O., Santerre, A.L., Pareilleux, A., Prome, D., Prome, J.C., Laussac, J.P. \& Goma, G. (1994): Pigment of Monascus. J. Food Sci., 59, 862-865. 
Booyens, J., Labuschagne, M.C. \& Thantsha, M.S. (2014): In vitro antibacterial mechanism of action of crude garlic (Allium sativum) clove extract on selected probiotic bifidobacterium species as revealed by SEM, TEM, and SDS-PAGE analysis. Probiotics Antimicro., 6, 82-87.

Cloete, T.E., Thantsha, M.S., Maluleke, M.R. \& Kirkpatrick, R. (2009): The antimicrobial mechanism of electrochemically activated water against Pseudomonas aeruginosa and Escherichia coli as determined by SDS-PAGE analysis. J. Appl. Microbiol., 107, 379-384.

Kiм, C., Jung, H., Kiм, J.H. \& Shin, C.S. (2006a): Effect of Monascus pigment derivatives on the electrophoretic mobility of bacteria, and the cell adsorption and antibacterial activities of pigments. Colloid Surface B., 47, 153-159.

Kiм, C., Jung, H., Kıм, Y.O. \& Shin, C.S. (2006b): Antimicrobial activities of amino acid derivatives of Monascus pigments. FEMS Microbiol. Lett., 264, 117-124.

Kim, H.J., Suh, H.J., LeE, C.H., Kim, J.H., Kang, S.C., PARK, S. \& Kim, J.S. (2010): Antifungal activity of glyceollins isolated from soybean elicited with Aspergillus sojae. J. Agr. Food Chem., 58, 9483-9487.

Li, C.L., Zhu, Y., Wang, Y.Y., Zhu, J.S., Chang, J. \& Kritchevsky, D. (1998): Monascus purpureus-fermented rice (red yeast rice): a natural food product that lowers blood cholesterol in animal models of hypercholesterolemia. Nutr. Res., 18, 71-81.

Li, J., Lei, Z.T., Li, L.G., XIE, R.J., XI, W.P., Guan, Y., Sumner, L.W. \& Zhou, Z.Q. (2014a): Antifungal activity of citrus essential oils. J. Agr. Food. Chem., 62, 3011-3033.

Li, Y.Q., HAN, Q., Feng, J.L., Tian, W.L. \& Mo, H.Z. (2014b): Antibacterial characteristics and mechanisms of ع-poly-lysine against Escherichia coli and Staphylococcus aureus. Food Control, 43, $22-27$.

Navarro García, V.M., Gonzalez, A., Fuentes, M., Aviless, M., Rios, M.Y., Zepeda, G. \& Rojas, M.G. (2003): Antifungal activities of nine traditional Mexican medicinal plants. J. Ethnopharmacol., 87, 85-88.

Sato, K., Goda, Y., Sakamoto, S.S., Shibata, H., Maitani, T. \& Yamada, T. (1997): Identification of major pigments containing D-amino acid units in commercial Monascus pigments. Chem. Pharm. Bull., 45, 227-229.

Siтонy, M.Z., Mahgoub, S.A. \& Osman, A.O. (2012): In vitro and in situ antimicrobial action and mechanism of glycinin and its basic subunit. Int. J. Food Microbiol., 154, 19-29.

Su, N.W., LiN, Y.L., LeE, M.H. \& Ho, C.Y. (2005): Ankaflavin from Monascus-fermented red rice exhibits selective cytotoxic effect and induces cell death on Hep G2 cells. J. Agr. Food Chem., 53, 1949-1954.

TAng, Y.L., Shi, Y.H., Wei, Z., Gang, H. \& Le, G.W. (2009): Discovery of a novel antimicrobial peptide using membrane binding-based approach. Food Control, 20, 149-156.

Ungureanu, C. \& Ferdes, M. (2010): Antibacterial and antifungal activity of red rice obtained from Monascus purpureus. IBIC2010: $2^{\text {nd }}$ International Conference on Industrial Biotechnology. Chem. Eng. Trans., 20, $223-228$.

WANG, Q., WANG, H.T. \& XIE, M.J. (2010): Antibacterial mechanism of soybean isoflavone on Staphylococcus aureus. Arch. Microbiol., 192, 893-898.

WANG, Y., Lu, Z.X., Wu, H. \& Lv, F.X. (2009): Study on the antibiotic activity of microcapsule curcumin against foodborne pathogens. Int. J. Food Microbiol., 136, 71-74.

Wild, D., Tóth, G. \& HumpF, H.U. (2002): New Monascus metabolite isolated from red yeast rice (angkak red koji). J. Agr. Food Chem., 50, 3999-4002.

Wong, H.C. \& BAU, Y.S. (1977): Pigmentation and antibacterial activity of fast neutron- and X-ray-induced strains of Monascus purpureus Went. Plant Physiol., 60, 578-581.

Wong, H.C. \& KoeHLER, P.E. (1981): Production and isolation of an antibiotic from Monascus purpureus and its relationship to pigment production. J. Food Sci., 46, 589-592.

Xie, X.J., Wang, Y.F., Zhang, S.Z., Zhang, G.D., Xu, Y.C., Bi, H.H., Daugherty, A. \& Wang, J.A. (2012): Chinese red yeast rice attenuates the development of angiotensin II-induced abdominal aortic aneurysm and atherosclerosis. J. Nutr. Biochem., 23, 549-556.

YAnG, C.W. \& Mousa, S.A. (2012): The effect of red yeast rice (Monascus purpureus) in dyslipidemia and other disorders. Complement. Ther. Med., 20, 466-474.

YANG, J., Sun, G.J., LI, Y.Q., Cui, K.Y. \& Mo, H.Z. (2016): Antibacterial characteristics of glycinin basic polypeptide against Staphylococcus aureus. Food Sci. Biotechnol., 25, 1477-1483.

Zнао, G.P., LI, Y.Q., Sun, G.J. \& Mo, H.Z. (2017): Antibacterial actions of glycinin basic peptide against Escherichia coli. J. Agr. Food Chem., 65, 5173-5180.

Zнао, G.P., Li, Y.Q., YAnG, J. \& Cui, K.Y. (2016): Antibacterial characteristics of orange pigment extracted from Monascus pigments against Escherichia coli. Czech J. Food Sci., 34, 197-203. 